\title{
PERLINDUNGAN HUKUM NASABAH BANK DALAM HAL PEMBERIAN INFORMASI NASABAH KEPADA PIHAK FINTECHLENDING BERDASARKAN PRINSIP KERAHASIAAN
}

\author{
Galih Raka S ${ }^{1}$, Rani Apriani ${ }^{2}$ \\ ${ }^{1}$ Fakultas Hukum Universitas Singaperbangsa Karawang \\ Email : galihrakas112@gmail.com \\ ${ }^{2}$ Fakultas Hukum Universitas Singaperbangsa Karawang \\ Email : $\underline{\text { rani.apriani80488@gmail.com }}$
}

\begin{abstract}
Bank is a financial institution that collects funds and distributes public funds, in accordance with Article 3 of the Banking Law. Banking institutions have a very important role, especially in moving the economy of a country. The role of banking cannot be separated from the enactment of Law Number 10 of 1998 concerning Banking. In carrying out its functions and duties, banking cannot be separated from customers, be they depositors or borrowing customers. In carrying out its functions, the Bank is bound by several principles, one of which is the principle of confidentiality. The principle of bank secrecy is regulated in Article 4- to Article 47A of the Banking Law. The principle of confidentiality is very important to be maintained by the bank as a financial service provider, this is related to public trust in the banking sector itself. Banks are prohibited from opening data from customers without permission from the BI leadership or if the law says otherwise. Banks are prohibited from disclosing secrets related to financial data or loans from customers to third parties, in this case the fintech lending party. Banks as service providers will certainly comply with the Consumer Protection Law. The purpose of this paper is to identify and understand the principles of banking confidentiality. The method used in this paper is normative juridical, by examining primary and secondary legal materials, especially in terms of legislation.
\end{abstract}

Keywords: Legal Protection, Bank customers, Fintech Lending, Principle of confidentiality

\begin{abstract}
Abstrak
Bank adalah sebuah lembaga keuangan yang menghimpun dana dan penyalur dana masyarakat, sesuai dengan Pasal 3 UU Perbankan. Lembaga perbankan mempunyai peran yang sangat penting khususnya untuk menggerakan perekonomian suatu Negara. Peran perbankan tidak terlepas dari pada telah ditetapkannya Undang-Undang Nomor 10 Tahun 1998 Tentang Perbankan. Dalam menjalankan fungsi serta tugasnya, perbankan tidak terlepas dari nasabah baik itu nasabah penyimpan ataupun nasabah peminjam. Bank dalam menjalankan fungsinya terikat kepada beberapa prinsip, salah satunya adalah prinsip kerahasiaan. Prinsip kerahasiaan bank diatur dalam Pasal 4sampai Pasal 47A UU Perbankan. Prinsip kerahasiaan tersebut sangat penting untuk dijaga oleh pihak bank selaku penyedia jasa keuangan, hal ini terkait kepercayaan masyarakat kepada pihak perbankan itu sendiri. Bank dilarang membuka data dari nasabah tanpa izin dari Pimpinan BI atau apabila UU mengatakan lain. Bank dilarang membuka rahasia terkait data keuangan ataupun pinjaman dari nasabah kepada pihak ketiga, yang dalam hal ini adalah pihak fintech lending. Bank sebagai penyedia jasa tentu akan ikut tunduk kepada UU perlindungan Konsumen. Tujuan penulisan ini adalah untuk mengetahui serta memahami prinsip kerahasiaan perbankan. Metode yang digunakan dalam penulisan ini adalah yuridis normatif, dengan mengkaji bahan-bahan hukum primer dan sekunder, Khususunya dalam hal Perundang-undangan.
\end{abstract}

Kata Kunci: Perlindungan Hukum, Nasabah Bank, Fintech Lending, Prinsip Kerahasiaan 


\section{Pendahuluan}

\subsection{Latar Belakang}

Berkembangnya aktivitas perekonomian masyarakat menyebabkan dibutuhkannya sebuah institusi yang berwenang untuk mengelola keuangan. Menurut Surat Keputusan Menteri Keuangan Republik Indonesia No. 792 tahun 1990, lembaga keuangan diberi batasan sebagai semua badan yang kegiatannya di bidang keuangan, melakukan penghimpunan dan penyaluran dana kepada masyarakat, terutama guna membiayai investasi perusahaan. ${ }^{1}$ Bank merupakan lembaga keuangan yang sangat dekat dengan masyarakat yang telah diberikan intermediasi oleh pemerintah untuk mempercepat pembangunan ekonomi. Hal demikian berdampak kepada para pelaku perekonomian yang sedang membutuhkan pendanaan dengan tujuan untuk menunjang kegiatannya dapat terpenuhi dan dapat membuat roda perekonomian bergerak.

Lembaga perbankan mempunyai peranan yang sangat penting dan strategis dalam menggerakan suatu perekonomian Negara. Hal ini sebenarnya tidak terlepas dari tujuan didirikannya bank itu sendiri. Menurut Pasal 4 UU Perbankan mengatakan bahwa tujuan didirikannya bank untuk menunjang pelaksanaan pembangunan nasional dalam rangka meningkatkan pemerataan, pertumbuhan ekonomi dan stabilitas ke arah peningkatan kesejahteraan rakyat banyak.

Peran perbankan tidak terlepas dari ketetapan sistem perbankan yang telah ditetapkan pada Undang-Undang No. 10 Tahun 1998 menjelaskan bahwa Bank adalah badan usaha yang menghimpun dana dari masyarakat dalam bentuk simpanan dan menyalurkannya kepada masyarakat dalam bentuk kredit dan atau bentuk-bentuk lainnya dalam rangka meningkatkan taraf hidup rakyat banyak. ${ }^{2}$ Bank memberikan fungsi sebagai suatu lembaga intermediasi memberikan pengaruh terhadap perekonomian di suatu negara. Bank memberikan kontribusi yang nyata kepada dinamika perekonomian. Perbankan diharapkan mampu mengendalikan sistem kestabilan moneter di suatu negara, yaitu kontribusinya dalam mengatur perputaran uang yang merupakan fungsi dari perbankan sendiri. Perbankan memiliki peran untuk menghimpun dan menyalurkan dana masyarakat. Peranan perbankan ini yang merupakan aktifitas guna menunjang kelancaran perekonomian negara. sehubungan dengan hal ini, tingkat kepercayaan yang diberikan oleh masyarakat sangatlah penting. Guna meningkatkan rasa kepercayaan yang diberikan oleh masyarakat kepada bank adalah dengan memberikan imbalan jasa yang dapat berupa bunga, bagi hasil, pelayanan, dan lain sebagainya.

Dari waktu ke waktu kondisi dunia perbankan di Indonesia telah mengalami banyak perubahan. Selain disebabkan oleh perkembangan internal dunia perbankan, juga tidak terlepas dari pengaruh perkembangan di luar dunia perbankan, seperti sektor riil dalam perekonomian, politik, hukum, serta sosial. Perkembangan faktor internal dan external tersebut menyebabkan kondisi perbankan di Indonesia dapat dikelompokan dalam beberapa periode. Masing-masing periode tersebut mempunyai ciri khusus yang tidak dapat disamakan dengan periode lainnya. Deregulasi di sektor riil dan moneter yang dimulai sejak tahun 1980-an serta terjadinya krisis ekonomi di Indonesia sejak akhir tahun

${ }^{1}$ Binti Nur Aisyah. (2020). Pertumbuhan Perbankan Syariah di Indonesia. Jurnal Ahkam. Vol. 14. No. 1, hlm. 85 .

${ }^{2}$ Thomas Suyatno. (2001). Kelembagaan Perbankan. Jakarta: Gramedia Pustaka Utama, hlm.1. 
1990-an adalah dua peristiwa utama yang telah menyebabkan munculnya periode-periode kondisi perbankan di Indonesia sampai dengan tahun 2000.

Sejak tahun 1998- sekarang, Pemerintah telah banyak mengeluarkan berbagai kebijakan paket deregulasi di bidang keuangan, moneter, dan perbankan. Sejak saat itu dunia perbankan semakin semarak, karena di mana-mana bank-bank baru bermunculan baik itu swasta maupun bank milik pemerintah. Pertumbuhan sektor perbankan yang kian mengalami perkembangan, menuntut perbankan sebagai lembaga penyedia jasa melakukan berbagai terobosan dan inovasi terbaru dengan tujuan untuk perbaikan layanan serta menarik minat dari masyarakat itu sendiri.

Berbagai perkembangan yang ada sekarang dalam sektor perbankan nampaknya tidak terlepas dari berkembangnya sistem informasi serta teknologi. Saat ini sudah banyak bank yang telah menyediakan akses mobile untuk mengetahui informasi keuangan. Kondisi tersebut merupakan salah satu perbaikan layanan terhadap nasabah, karena pada kenyataannya dalam melaksanakan transaksi perbankan setiap nasabah minimal membutuhkan waktu kurang lebih 10 menit berada dalam antrian. Hal tersebut akan cenderung berdampak merugikan bagi para nasabah jika waktu serta peluang bisnis mereka tersita hanya untuk bertransaksi di bank.

Mobile banking merupakan layanan perbankan yang berfungsi untuk memudahkan nasabah dalam melakukan transaksi perbankan tanpa perlu datang ke bank atau ATM kecuali penarikan uang cash. Keunggulan mobile banking yaitu nasabah dapat melakukan transaksi dimana saja dan kapan saja tanpa dibatasi waktu. Layanan pada mobile banking meliputi: transaksi finansial, transaksi non finansial, transfer dana, cek saldo dan pembayaran tagihan yang dilakukan lewat telepon seluler. Hal serupa terjadi pada proses perbankan lainnya yakni kredit keuangan/pinjaman, dimana pada masa sekarang ini masyarakat ataupun pelaku usaha bisa mendapatkan pinjaman (kredit) dana dari penyedia jasa keuangan dengan memakai telepon seluler. Kredit dalam kegiatan perbankan merupakan kegiatan usaha yang paling utama, karena pendapatan terbesar dari usaha perbankan adalah berasal dari pendapatan pada kegiatan usaha kredit, yaitu berupa bunga dan provisi.

Dewasa ini, kemunculan Fintech Peer-to-Peer Lending atau Layanan Pinjam Meminjam Uang Berbasis Teknologi Informasi (LPMUBTI) turut ikut serta dalam sektor keuangan dan perbankan. Dimana, Fintech Peer-to-Peer Lending menghadirkan salah satu inovasi pada bidang keuangan dengan pemanfaatan teknologi yang memungkinkan pemberi pinjaman dan penerima pinjaman melakukan transaksi pinjam meminjam tanpa harus bertemu langsung. Mekanisme transaksi pinjam meminjam dilakukan melalui sistem yang telah disediakan oleh Penyelenggara Fintech Lending, baik melalui aplikasi maupun laman website.

Kemunculan berbagai inovasi dalam sektor perbankan tersebut memunculkan pula berbagai masalah yang kian kompleks. Masalah-masalah yang munculpun cenderung bersifat teknologi, seperti misalnya terkait kebocoran data nasabah pada perbankan yang ditimbulkan akibat system eror ataupun human eror serta masalah lainnya yang biasa timbul dalam dunia perbankan pada masa kini.

\subsection{Rumusan Masalah}

Berdasarkan latar belakang di atas, maka penulis tertarik untuk mengkaji lebih dalam dan dituangkan dalam bentuk riset dan jurnal ilmiah. Adapun yang menjadi rumusan masalahnya yakni sebagai berikut : 
1. Bagaimana konsep pengaturan perlindungan hukum nasabah bank dalam hal pemberian informasi nasabah kepada pihak fintech lending berdasarkan prinsip kerahasiaan?

2. Bagaimana perlindungan hukum nasabah bank dalam hal pemberian informasi nasabah kepada pihak fintech lending berdasarkan prinsip kerahasiaan?

\section{Metode Penelitian}

Metode penelitian yang digunakan oleh penulis dalam penulisan jurnal hukum ini adalah penelitian hukum normatif atau doktrinal. Penelitian hukum normatif yang juga disebut sebagai penelitian kepustakaan atau doktrinal. Karena dalam penulisan jurnal hukum ini mengacu kepada peraturan-peraturan yang tertulis dan bahan-bahan hukum lainnya. ${ }^{3}$

\section{Hasil dan Pembahasan}

\subsection{Konsep Pengaturan Perlindungan Hukum Nasabah Bank dalam Hal Pemberian Informasi Nasabah Kepada Pihak Fintech Lending Berdasarkan Prinsip Kerahasiaan}

3.1.1. Prinsip Kerahasiaan dalam Perbankan Menurut Undang Nomor 10 Tahun 1998 Tentang Perubahan Atas Undang-Undang Nomor 7 Tahun 1992 Tentang Perbankan dan Aturan Pelaksanaanya

Undang-Undang Nomor 10 Tahun 1998 diatur tentang fungsi perbankan, yaitu dalam Pasal 3 yang berbunyi "Fungsi utama perbankan Indonesia adalah sebagai penghimpun dan penyalur dana masyarakat". Dari ketentuan ini tercermin fungsi bank sebagai perantara pihak-pihak yang memiliki kelebihan dana (surplus of funds) dengan pihak-pihak yang kekurangan dan memerlukan dana (lacks of funds). Hal ini juga yang menyebabkan lembaga bank disebut sebagai lembaga kepercayaan artinya pihak yang kelebihan dana mempercayakan sepenuhnya kepada bank untuk mengelola dananya termasuk menyalurkannya kepadsa pihak yang kekurangan atau memerlukan dana berupa kredit. Dengan kepercayaan tersebut, sudah sewajarnya jika pihak bank melindungi nasabah dalam hal "keadaan keuangan nasabah" yang lazimnya disebut dengan "prinsip kerahasiaan". Kemampuan menjaga kerahasiaan bank sangat penting dimiliki oleh setiap pelaku jasa keuangan (perbankan). Yang mana, bank sebagai lembaga yang oleh masyarakat dianggap mampu menjaga simpanan dan ataupun pinjaman nasabah dari segala bentuk penyalahgunaan. Kehidupan bank sangat bergantung kepada kepercayaan masyarakat. Masyarakat hanya akan menjadi nasabah bank yang bersangkutan apabila dari bank ada jaminan, bahwa terhadap keadaan rekening atas uang yang ada pada bank tersebut dapat dipertahankan kerahasiannya. ${ }^{4}$

Menurut Pasal 1 angka 2 Undang-Undang Nomor 10 Tahun 1998 Tentang Perubahan Atas Undang-Undang Nomor 7 Tahun 1992 Tentang Perbankan menyebutkan pengertian bank adalah badan usaha yang menghimpun dana dari masyarakat dalam bentuk simpanan dan menyalurkannya kepada masyarakat dalam bentuk kredit dan atau bentuk-bentuk lainnya dalam rangka meningkatkan taraf hidup rakyat banyak. Sedangkan pengertian Perbankan menurut Pasal 1 angka 1 UU Perbankan, Perbankan adalah Perbankan adalah segala sesuatu yang menyangkut tentang bank, mencakup kelembagaan, kegiatan usaha, serta cara dan proses dalam melaksanakan kegiatan usahanya.

\footnotetext{
${ }^{3}$ Mamudji Sri, Soerjono Soekanto. (2004). Penelitian Hukum Normatif. Jakarta: Raja Grafindo

Persada, hlm. 14

${ }^{4}$ Moch Anwar. (1986). Tindak Pidana di Bidang Perbankan. Bandung: Alumni, hlm. 85
} 
Perbankan di Indonesia mempunyai tujuan yang strategis dan tidak semata-mata berorientasi ekonomis, tetapi juga berorientasi kepada hal-hal yang non ekonomis seperti masalah menyangkut stabilitas nasional yang mencakup antara lain stabilitas politik dan stabilitas sosial. Secara lengkap mengenai hal ini diatur dalam ketentuan Pasal 4 UndangUndang Nomor 10 Tahun 1998 tentang Perbankan, yang berbunyi “Perbankan Indonesia bertujuan menunjang pelaksanaan pembangunan nasional dalam rangka meningkatkan pemerataan, pertumbuhan ekonomi, dan stabilitas nasional ke arah peningkatan kesejahteraan rakyat banyak".

Kerahasiaan informasi yang terlahir dalam kegiatan perbankan, diperlukan baik itu untuk kepentingan bank maupun untuk kepentingan nasabah itu sendiri. Hal tersebut didasarkan atas Asas kerahasiaan. Asas kerahasiaan adalah asas yang mengharuskan atau mewajibkan bank sebagai lembaga keuangan untuk merahasiakan segala sesuatu yang berhubungan dengan keuangan dan lain-lain dari nasabah yang menurut kelaziman dunia perbankan, wajib dirahasiakan. ${ }^{5}$ Ketentuan tersebut menegaskan bahwa lembaga perbankan harus memegang teguh keterangan yang tercatat olehnya, ketentuan ini juga berlaku bagi pihak terafiliasi dalam kegiatan operasional perbankan. ${ }^{6}$ Y. Sri Susilo, Sigit Triandaru, dan A. Totok Budi Santoso, mengemukakan bahwa: "Salah satu faktor yang dapat mempengaruhi kadar kepercayaan masyarakat kepada bank adalah terjamin atau tidaknya rahasia nasabah yang ada di bank. Data nasabah yang berada di bank,baik data keuangan maupun nonkeuangan, seringkali merupakan suatu data yang tidak ingin diketahui oleh orang atau pihak lain. Jumlah kekayaan seseorang yang disimpan di bank bagi nasabah tertentu merupakan sesuatu yang perlu dirahasiakan dari orang lain". ${ }^{7}$

Muhammaa Djumhana berpendapat bahwa pengertian rahasia bank bersifat nisbi dan mutlak. Rahasia bank bersifat nisbi artinya bank diperbolehkan membuka rahasia nasabahnya apabila untuk suatu kepentingan mendesak, misalnya demi kepentingan negara, sedangkan rahasia bank bersifat mutlak artinya bank berkewajiban menyimpan rahasia nasabah yang diketahui oleh bank karena kegiatan usahanya dalam keadaan apapun, biasa atau dalam keadaan luar biasa.

Pendirian aliran nisbi akan bersedia melepaskan kewajibannya untuk menyimpan rahasia demi kepentingan masyarakat, yang dalam praktiknya berpijak pada asas proporsional dan asas subsider. Asas proporsional menghendaki pertimbangan kepentingan mana yang lebih berat, yaitu tidak membuka rahasia yang berarti menyimpan rahasia hanya memenuhi kepentingan terbatas yaitu kalangan perbankan, atau membuka rahasia demi kepentingan yang lebih besar yaitu kepentingan negara. Pertimbangan dalam memilih tersebut dihubungkan dengan pemilihan kepentingan ${ }^{8}$

Pada dasarnya setiap orang, baik sebagai pribadi maupun sebagai pengusaha, tidak menginginkan keadaan mengenai pribadinya termasuk keadaan keuangannya diketahui oleh orang lain. Tiap-tiap kepentingan dari setiap orang itu harus mendapat perhatian dan dihormati sepenuhnya oleh siapapun juga termasuk negara. Oleh karena itu, maka hal tersebut perlu dilindungi dengan mempergunakan hukum pidana yaitu sejauh kepentingan itu secara langsung maupun tidak langsung.

\footnotetext{
${ }^{5}$ Chainur Arrasjid. (2000). Dasar-Dasar Ilmu Hukum Jakarta: Sinar Grafika. hlm. 37

${ }^{6}$ Muhamad Djumhana. (2008) Asas-Asas Hukum Perbankan Indonesia. Bandung: Citra Aditya Bakti, hlm. 27

${ }^{7}$ Y. Sri Susilo, Sigit Triandaru, dan A.Totok Budi Santoso. (2000). Bank dan Lembaga Keuangan Lainnya. Jakarta: Salemba Empat, hlm. 35

${ }^{8}$ Muhammad Djumhana. (1966). Hukum Perbankan diIndonesia. Bandung: Citra Aditya Bakti, hlm. 116-117.
} 
Bagi seorang pengusaha, kerahasiaan tersebut sangatlah penting artinya demi menunjang kelancaraan perusahannya, karena tanpa hal tersebut setiap orang atau pengusaha lain akan dengan mudah mempelajari keuangan perusahaannya yang kemudian bisa dipergunakan untuk mempersulit atau menjatuhkan usahanya. Keadaan seperti itu benar-benar disadari oleh dunia perbankan sehingga bank merasa perlu untuk merahasiakan keadaan keuangan nasabah yang dipercayakan kepadanya. Tindakan tersebut dalam dunia perbankan dikenal dengan Rahasia Bank. ${ }^{9}$ Sedangkan, bagi peroarangan kerahasiaan bank ini sangat diperlukan khususnya kerahasiaan yang menyangkut kredit/pinjaman nasabah. Pihak perbankan pada dasarnya dituntut untuk menjaga data nasabah (kredit dari nasabah) demi dan untuk kenyamanan nasabah serta menjaga kepercayaan masyarakat terhadap bank itu sendiri. Baru-baru ini terjadi kepada seorang wanita yang menceritakan pengalamannya terkait perbankna, wanita tersebut menceritakan pengalamannya dalam bentuk video serta mengunggah video tersebut ke media sosial Instagram. Dalam video tersebut diceritakan keinginan wanita tersebut untuk mengajukan kredit kepada salah satu bank di Indonesia, namun pengajuannya ditunda dan terancam gagal. Wanita tersebut juga menjelaskan bahwa pihak bank membatalkan pengajuan kredit wanita tersebut 1 hari sebelum proses pencairan. Diketahui, wanita tersebut mempunyai cicilan kepada salah satu fintech lending. Hal demikian perlu dikaji lebih dalam dengan menggunakan hukum positif Indonesia.

Rahasia bank adalah segala sesuatu yang berhubungan dengan keuangan dan halhal lain dari nasabah bank yang menurut kelaziman dunia perbankan tidak boleh secara terbuka diungkapkan kepada pihak masyarakat. Dalam hubungan ini yang menurut kelaziman wajib dirahasiakan oleh bank, adalah seluruh data dan informasi mengenai segala sesuatu yang berhubungnan dengan keuangan, dan hal-hal lain dari orang, dan badan yang diketahui oleh bank karena kegiatan usahanya.

Undang-undang Perbankan Indonesia menganut pengertian rahasia bank yang bersifat relatih. ${ }^{10}$ Artinya rahasia bank memungkinkan untuk dibuka dengan alasan kepentingan umum. ${ }^{11}$ Istilah rahasia bank mengacu kepada rahasia dalam hubungan antara bank dengan nasabahnya. Akan tetapi, rahasia-rahasia lain yang bukan merupakan rahasia antara bank dengan nasabah, namun juga bersifat "rahasia", tidak tergolong ke dalam istilah "rahasia bank"menurut Undang-Undang Perbankan. Rahasia-rahasia lain yang bukan rahasia bank tersebut, misalnya rahasia mengenai data dalam hubungan dengan pengawasan bank oleh Bank Indonesia, sebagaimana dimaksud dalam pasal 30 ayat (3) dan pasal 33 Undang-Undang perbankan. ${ }^{12}$

Berdasarkan ketentuan dalam Undang-Undang Nomor 10 Tahun 1998 tentang Perubahan Atas Undang-Undang Nomor 7 Tahun 1992 tentang Perbankan, dikatakan dalam bagian Pasal 1 angka 28 yang menjelaskan mengenai rahasia bank, menerangkan bahwa rahasia bank adalah segala sesuatu yang berhubungan dengan keterangan mengenai nasabah penyimpanan dan simpanannya.

Kerahasiaan informasi yang terlahir dalam kegiatan perbankan ini diperlukan baik untuk kepentingan bank maupun untuk kepentingan nasabah itu sendiri. Oleh karenanya lembaga perbankan harus memegang teguh keterangan yang tercatat padanya. ${ }^{13}$

\footnotetext{
9 Muhamad Djumhana. (1966). Rahasia Bank (Ketentuan dan Penerapannya di Indonesia). Bandung: Citra Aditya Bakti, hlm. 129

10 Ibid hlm. 111

11 Yunus Husein, Op.cit. hlm. 7

${ }^{12}$ Munir Fuady. (2001). Hukum Perbankan Modern. Bandung: Citra Adiyta Bakti, hlm.87

13 Zainal Asikin. (1995). Pokok-Pokok Hukum Perbankan di Indonesia. Jakarta: Raja Grafindo Persada, hlm. 53
} 
Dari rumusan Pasal 40 Undang-Undang No. 10 Tahun 1998, secara eksplisit disebutkan bahwa lingkup rahasia bank adalah menyangkut bukan saja simpanan nasabah tetapi juga identitas nasabah penyimpan yang memiliki simpanan itu. Bahkan dalam rumusan Pasal 40 itu, Nasabah Penyimpan disebut lebih dahulu daripada kata "simpanannya". Dari hal tersebut dapat disimpukan bahwa dalam pikiran pembuat undang-undang, identitas nasabah penyimpannya lebih penting daripada simpanannya, atau untuk menekankan bahwa merahasiakan identitas nasabah penyimpannya sama pentingnya dengan merahasiakan simpanannya. ${ }^{14}$

Ketentuan Rahasia bank tersebut ditujukan untuk kepentingan nasabah agar kerahasiaannya terlindungi. Kerahasiaan tersebut menyangkut keadaan keuangannya. Selain itu, rahasia bank diperuntukkan juga bagi kepentingan bank, agar dapat dipercaya dan menjaga kelangsungan hidupnya terjaga. Di Indonesia, pengaturan rahasia bank lebih dititikberatkan pada alasan untuk kepentingan bank, sebagaimana jelas diatur di dalam Pasal 40 UU Perbankan yang menegaskan bahwa kerahasiaan ini diperlukan untuk kepentingan bank itu sendiri yang memerlukan kepercayaan masyarakat yang menyimpan uangnya di bank.

Ada 5 alasan yang mendasari kewajiban bank untuk merahasiakan segala sesuatu tentang nasabah dan simpanannya, antara lain:

1. Personal privacy;

2. Hak yang timbul dari hubungan perikatan antara bank dan nasabah;

3. Peraturan perundang-undangan yang berlaku;

4. Kebiasaan atau kelaziman dalam dunia perbankan;

5. Karakteristik kegiatan usaha bank sebagai suatu "lembaga kepercayaan" yang harus memegang teguh kepercayaan nasabah yang menyimpan uangnya di bank. ${ }^{15}$

Dibeberapa negara, lingkup dari rahasia bank tidak ditentukan hanya terbatas kepada keadaan keuangan nasabah saja, tetapi meliputi pula identitas nasabah yang bersangkutan. Kemudian perkembangan kemajuan ilmu pengetahuan dan teknologi khususnya dibidang komunikasi telah menyebabkan terintegrasinya sistem keuangan termasuk sistem perbankan yang menawarkan mekanisme lalu lintas antar negara yang dapat dilakukan dalam waktu yang sangat singkat.

Dalam menjalankan fungsi perbankan, lembaga perbankan di Indonesia berdasar kepada 4 prinsip, yang mana prinsip tersebut menjadi landasan untuk lembaga perbankan menjalankan fungsi serta kewajibannya sebagai lembaga perbankan yakni sebagai berikut:

1. Prinsip Kepercayaan ( fiduciary relation principle)

Prinsip kepercayaan adalah suatu asas yang melandasi hubungan antara bank dan nasabah bank. Bank berusaha dari dana masyarakat yang disimpan berdasarkan kepercayaan, sehingga setiap bank perlu menjaga kesehatan banknya dengan tetap memelihara dan mempertahankan kepercayaan masyarakat. Prinsip kepercayaan diatur dalam Pasal 29 ayat (4) UU No 10 Tahun 1998.

2. Prinsip Kehati-hatian (prudential principle)

Prinsip kehati-hatian adalah suatu prinsip yang menegaskan bahwa bank dalam menjalankan kegiatan usaha baik dalam penghimpunan terutama dalam penyaluran dana kepada masyarakat harus sangat berhati-hati. Tujuan dilakukannya prinsip kehati-hatian ini agar bank selalu dalam keadaan sehat menjalankan

${ }^{14}$ Eddy Rifai. (2018). Pembukaan Rahasia Bank Untuk Kepentingan Peradilan dalam Perkara Pidana. Lampung: Universitas Lampung, hlm. 7

${ }^{15}$ Yunus Husein. (2003). Rahasia Bank Privasi Versus Kepentingan Umum Jakarta: Pascasarjana Fakultas Hukum Universitas Indonesia, hlm.139 
usahanya dengan baik dan mematuhi ketentuan-ketentuan dan norma-norma hukum yang berlaku di dunia perbankan. Prinsip kehati-hatian tertera dalam Pasal 2 dan Pasal 29 ayat (2) UU No 10 tahun 1998.

3. Prinsip Kerahasiaan ( secrecy principle)

Prinsip kerahasiaan bank diatur dalam Pasal 40 sampai dengan Pasal 47 A UU No 10 Tahun 1998. Menurut Pasal 40 bank wajib merahasiakan keterangan mengenai nasabah penyimpan dan simpanannya. Namun dalam ketentuan tersebut kewajiban merahasiakan itu bukan tanpa pengecualian. Kewajiban merahasiakan itu dikecualikan untuk dalam hal-hal untuk kepentingan pajak, penyelesaian utang piutang bank yang sudah diserahkan kepada badan Urusan Piutang dan Lelang / Panitia Urusan Piutang Negara (UPLN/PUPN), untuk kepentingan pengadilan perkara pidana, dalam perkara perdata antara bank dengan nasabah, dan dalam rangka tukar menukar informasi antar bank.

Menurut Muhamad Djumhana dalam bukunya Hukum Perbankan di Indonesia, dengan adanya jaminan kerahasiaan atas semua data masyarakat dalam hubungannya dengan bank, maka masyarakat memercayai bank tersebut. Selanjutnya, mereka akan memercayakan uangnya pada bank atau memanfaatkan jasa bank. Kepercayaan masyarakat lahir apabila dari bank ada jaminan bahwa pengetahuan bank tentang simpanan dan keadaan keuangan nasabah tidak akan disalahgunakan.16

4. Prinsip Mengenal Nasabah ( know how costumer principle)

Prinsip mengenal nasabah adalah prinsip yang diterapkan oleh bank untuk mengenal dan mengetahui identitas nasabah, memantau kegiatan transaksi nasabah termasuk melaporkan setiap transaksi yang mencurigakan. Prinsip mengenal nasabah nasabah diatur dalam Peraturan Bank Indonesia No.3/10/PBI/2001 tentang Penerapan Prinsip Mengenal nasabah. Tujuan yang hendak dicapai dalam penerapan prinsip mengenal nasabah adalah meningkatkan peran lembaga keuangan dengan berbagai kebijakan dalam menunjang praktik lembaga keuangan, menghindari berbagai kemungkinan lembaga keuangan dijadikan ajang tindak kejahatan dan aktivitas illegal yang dilakukan nasabah, dan melindungi nama baik dan reputasi lembaga keuangan.

Terkait prinsip kerahasiaan yang sudah dipaparkan secara singkat diatas, lebih lanjut diatur dalam Peraturan Bank Indonesia PBI No. 2/ 19/ PBI/ 2000 Tentang Persyaratan dan Tata Cara Pemberian Perintah atau Izin Tertulis Membuka Rahasia Bank. Dalam pearBuran Bank Indonesia Pasal 2 ayat (1) mengatakan bahwa bank wajib merahasiakan segala sesuatu yang berhubungan dengan keterangan mengenai Nasabah Penyimpan dan Simpanan Nasabah. Kemudian, keterangan mengenai Nasabah selain Nasabah Penyimpan bukan merupakan keterangan yang wajib dirahasiakan oleh Bank (Pasal 2 ayat (2) PBI No. 2/ 19/ PBI/ 2000).

Terdapat pengecualian dari ketentuan Pasal 2 ayat (1) tersebut, hal ini yang menjadikan Pihak Bank mampu membuka keterangan mengenai nasabah penyimpanannya maupun simpanannya. Hal demikian diatur dalam Ketentuan Pasal 2 ayat (4) PBI No. 2/ 19/ PBI/ 2000 Tentang Persyaratan dan Tata Cara Pemberian Perintah atau Izin Tertulis Membuka Rahasia Bank, serbagai berikut :

(4). Ketentuan sebagaimana dimaksud dalam ayat (1) tidak berlaku untuk:

a. kepentingan perpajakan;

${ }^{16}$ Muhammad Djumhana. op.cit. Hukum Perbankan di Indonesia. hlm. 157 
b. penyelesaian piutang Bank yang sudah diserahkan kepada Badan Urusan Piutang dan Lelang Negara/Panitia Urusan Piutang Negara;

c. kepentingan peradilan dalam perkara pidana;

d. kepentingan peradilan dalam perkara perdata antara Bank dengan Nasabahnya;

e. tukar menukar informasi antar Bank;

f. permintaan, persetujuan atau kuasa dari Nasabah Penyimpan yang dibuat secara tertulis;

g. permintaan ahli waris yang sah dari Nasabah Penyimpan yang telah meninggal dunia.

Kemudian, Ketentuan Pasal 3 sampai Pasal 7 mengatur mengenai pemberian izin untuk membuka rahasia bank dari keadaan keuangan Nasabah penyimpan yang ditujukan kepada Pimpinan Bank Indonesia. Lebih lanjut dijelaskan dalam Pasal 8 PBI No. 2/ 19/ PBI/ 2000 Tentang Persyaratan dan Tata Cara Pemberian Perintah atau Izin Tertulis Membuka Rahasia Bank menyatakan dengan tegas Bank dilarang memberikan keterangan tentang keadaan keuangan Nasabah Penyimpan selain yang disebutkan dalam perintah atau izin tertulis dari Pimpinan Bank Indonesia.

3. 1. 2. fintech lending di Indonesia

Berkaitan dengan penggunaan teknologi informasi dan inovasi di sektor jasa keuangan di Indonesia, beragam layanan keuangan yang memanfaatkan teknologi informasi atau yang disebut sebagai Financial Technology (Fintech) telah menjadi hal yang umum di masyarakat, baik yang ditawarkan oleh lembaga keuangan yang diawasi oleh OJK (seperti layanan pada bank, asuransi, atau lembaga keuangan terdaftar lainnya) maupun yang ditawarkan oleh perusahaan start-up (perusahaan yang belum terdaftar dan diawasi oleh OJK). Melihat perkembangan dan potensi tersebut, maka Fintech diharapkan dapat berperan sebagai pendukung untuk meningkatkan tingkat inklusi keuangan di Indonesia.

Fintech merupakan singkatan dari kata Financial Technology, yang dapat diartikan dalam bahasa Indonesia menjadi teknologi keuangan. Secara sederhana, Fintech dapat diartikan sebagai pemanfaatan perkembangan teknologi informasi untuk meningkatkan layanan di industri keuangan. Menurut National Digital Research Centre, Fintechadalah istilah yang digunakan untuk menyebut suatu inovasi di bidang jasa finansial. ${ }^{17}$ Definisi lainnya fintech adalah variasi model bisnis dan perkembangan teknologi yang memiliki potensi untuk meningkatkan industri layanan keuangan. ${ }^{18}$

Dalam era perkembangan teknologi dan digitalisasi, kebutuhan masyarakat akan kegiatan di sektor jasa keuangan yang mudah, cepat dan fleksibel pun meningkat. Kebutuhan masyarakat ini mendorong para pelaku jasa keuangan untuk terus melakukan inovasi dan transformasi dari transaksi secara tradisional ke dalam bentuk digital. Pelaku Usaha Jasa Keuangan (PUJK) juga dituntut untuk meningkatkan standar dan inovasi untuk menarik serta memenuhi kebutuhan masyarakat yang semakin modern. Saat ini, Pelaku Usaha Jasa Keuangan (PUJK) di Indonesia telah mulai mengembangkan produk inovatif dan menguatkan sistem teknologi dalam bisnis. Berdasarkan jenis Fintech yang berkembang di Indonesia, beberapa lembaga jasa keuangan yang sudah melakukan perkembangan dan inovasi Fintech terbagi ke dalam beberapa sektor, yaitu Layanan Perbankan Digital (Digital Banking), Pembiayaan dan Investasi, serta Asuransi. ${ }^{19}$

\footnotetext{
${ }^{17}$ www.maxmanroe.com

18 International Organization of Securities Commissions. IOSCO Research Report On Financial Technologies (Fintech). (Diakses pada 14 April 2021).

${ }^{19}$ Departemen Perlindungan Konsumen. op.cit, hlm. 20-23
} 
Teknologi Finansial dalam Peraturan Bank Indonesia Nomor 19/12/PBI/2017 mengatur tentang bagaimana penggunaan teknologi sistem keuangan yang menciptakan teknologi, layanan, produk, dan/atau model bisnis baru yang dapat berdampak positif terhadap kestabilan moneter, sistem keuangan, kelancaran, keandalan, efisiensi, dan keamanan sistem pembayaran. Penyelenggara layanan keuangan berbasis teknologi meliputi manajemen investasi dan manajemen resiko, pinjaman, pembiayaan dan penyedia modal, dan jasa finansial lainnya. ${ }^{20}$

Hingga sekarang ini, regulasi telah mengatur 6 (enam) kegiatan teknologi berbasis layanan keuangan yang diatur dalam sistem pembayaran dan sistem jasa keuangan di Indonesia, yaitu:

1. E-money, mempunyai dasar hukum yang diatur pada PBI No. 11/12/PBI/2009 jo. PBI No. 16/8/PBI/2014 jo. PBI No. 18/17/PBI/2016 mengenai Uang Elektronik. Uang elektronik merupakan alat yang digunakan untuk membayar yang terdapat unsur-unsur:

- Penerbit menerbitkan jumlah nilai uang yang telah disetorkan kepada penerbit oleh pemegang;

- Media seperti chip atau server yang dapat menyimpan nilai uang secara elektronik;

- Menjadi suatu alat bayar kepada penjual yang mana bukan merupakan penerbit uang elektronik; dan

- Sesuai dengan Undang-Undang yang mengatur mengenai perbankan, pemegang yang menyetor nilai uang elektronik dan penerbit yang mengelola bukanlah simpanan.

2. E-Wallet, mempunyai dasar hukum yang diatur pada PBI No. 18/40/PBI/2016 mengenai Penyelenggaraan Pemrosesan Transaksi Pembayaran. Ewallet merupakan media elektronik yang mana dapat digunakan untuk menyimpan data pembayaran di dalam sebuah kartu atau uang elektronik yang digunakan sebagai alat pembayaran dan menampung dana.

3. Payment Gateway, mempunyai dasar hukum yang diatur pada PBI No. 18/40/PBI/2016 mengenai Penyelenggaraan Pemprosesan Transaksi Pembayaran. Payment Gateway merupakan suatu media elektronik dimana penjual dapat melakukan proses transaksi pembayaran menggunakan Propietary Channel, uang elektronik, dan/atau kartu.

4. Peer to Peer (P2P) Lending, mempuyai dasar hukum yang diatur dalam POJK No. 77/POJK.01/2016 mengenai Layanan Pinjam Meminjam Uang Berbasis Teknologi Informasi. Dimana jenis ini merupakan pengelola media jasa keuangan yang dipertemukan antara penerima pinjaman dan pemberi pinjaman dalam hal melangsungkan perjanjian pinjam meminjam secara langsung dengan mata uang rupiah dengan menggunakan internet melalui sistem elektronik (Aplikasi).

5. Marketplace Reksadana, mempunyai dasar hukum yang diatur dalam POJK No. 39/POJK.04/2014 mengenai Agen Penjual Efek Reksadana. Dimana jenis ini (marketplace Reksadana) merupakan suatu kontrak kerjasama antara manajer investasi pengelola reksadana dengan pihak yang melakukan penjualan efek.

6. Marketplace Asuransi, mempunyai dasar hukum yang diatur pada POJK No. 69/POJK.05/2016 mengenai Penyelenggaraan Usaha Perusahaan Asuransi. Perusahaan Pialang Asuransi merupakan sebuah industri yang melakukan jasa keperantaraan dalam hal menutup asuransi / asuransi syariah dan/atau jasa

${ }^{20}$ Rahma, Tri Inda Fadhila. Loc. Cit., hlm. 644 
konsultasi serta melakukan penanganan mengenai penyelesaian klaim dengan dilakukan untuk dari atas nama tertanggung.

\subsection{Perlindungan Hukum Nasabah Bank dalam Hal Pemberian Informasi Nasabah Kepada Pihak Fintech Lending Berdasarkan Prinsip Kerahasiaan}

Perlindungan hukum adalah memberikan pengayoman kepada hak asasi manusia yang dirugikan orang lain dan perlindungan tersebut diberikan kepada masyarakat agar mereka dapat menikmati semua hak-hak yang diberikan oleh hukum atau dengan kata lain perlindungan hukum adalah berbagai upaya hukum yang harus diberikan oleh aparat penegak hukum untuk memberikan rasa aman, baik secara pikiran maupun fisik dari gangguan dan berbagai ancaman dari pihak manapun. ${ }^{21}$

Perlindungan hukum merupakan suatu hal yang melindungi subyek-subyek hukum melalui peraturan perundang-undangan yang berlaku dan dipaksakan pelaksanaannya dengan suatu sanksi. Perlindungan hukum dapat dibedakan menjadi dua, yaitu:

1. Perlindungan hukum preventif

Perlindungan yang diberikan oleh Pemerintah dengan tujuan untuk mencegah sebelum terjadinya pelanggaran. Hal ini terdapat dalam peraturan perundang-undangan dengan maksud untuk mencegah suatu pelanggaran serta memberikan rambu-rambu atau batasan-batasan dalam melakukan sutu kewajiban.

2. Perlindungan hukum represif

Perlindungan hukum represif merupakan perlindungan akhir berupa sanksi seperti denda, penjara, dan hukuman tambahan yang diberikan apabila sudah terjadi sengketa atau telah dilakukan suatu pelanggaran. ${ }^{22}$

Dalam hal terjadinya pemberian informasi secara sepihak yang dilakukan oleh pihak perbankan, tanpa ada pemberitahuan telebih dahulu dan/ atau bukan termasuk yang disebutkan dalam Ketentuan Pasal 2 ayat (4) No. 2/ 19/ PBI/ 2000 Tentang Persyaratan dan Tata Cara Pemberian Perintah atau Izin Tertulis Membuka Rahasia Bank yang dapat merugikan nasabah perbankan itu sendiri maka pertanggung jawabannya ada pada pihak perbankan atau disebut juga pelaku usaha.

Undang-undang Nomor 8 Tahun 1999 Tentang Perlindungan Konsumen "UU PK" memberikan definisi yang disebut dengan Perlindungan Konsumen, konsumen, dan pelaku usaha. Yang disebut dengan Perlindungan Konsumen menurut Pasal 1 angka 1 UU PK adalah Perlindungan konsumen adalah segala upaya yang menjamin adanya kepastian hukum untuk memberi perlindungan kepada konsumen. Selanjutnya, yang dimaksud dengan Konsumen merujuk kepada Pasal 1 angka 2 UU PK adalah Konsumen adalah setiap orang pemakai barang dan/atau jasa yang tersedia dalam masyarakat, baik bagi kepentingan diri sendiri, keluarga, orang lain, maupun makhluk hidup lain dan tidak untuk diperdagangkan. Kemudian yang dimaksud dengan Pelaku usaha menurut Pasal 1 angka 3 UU PK adalah setiap orang perseorangan atau badan usaha, baik yang berbentuk badan hukum maupun bukan badan hukum yang didirikan dan berkedudukan atau melakukan kegiatan dalam wilayah hukum negara Republik Indonesia, baik sendiri maupun bersamasama melalui perjanjian menyelenggarakan kegiatan usaha dalam berbagai bidang ekonomi.

Dalam sejarah perlindungan konsumen, dikenal adanya teori The Privity of Contract. Teori ini menyatakan bahwa pelaku usaha mempunyai kewajiban untuk melindungi konsumen, tetapi hal itu baru dapat dilakukan jika di antara mereka telah terjalin suatu hubungan kontraktual. Pelaku usaha tidak dapat disalahkan atas hal-hal di luar yang

${ }^{21}$ Satjipto Rahardjo. Perlindungan Hukum, melalui https://www.suduthukum.com, diakses Sabtu, 12 Januari 2019 Pukul 09.00 WIB.

22 Wildan Areza. Macam-Macam Perlindungan Hukum, melalui https:/kantorhukum-ss.com, diakses Sabtu, 12 Januari 2019 Pukul 09.00 WIB. 
diperjanjikan. Artinya, Konsumen boleh menggugat berdasarkan wanprestasi. (Sidharta, Jakarta, $2000: 52)$

Kemudian, dikenal pula adanya teori tanggung jawab pelaku usaha dalam hubungan-nya dengan negara. Dalam hal hubungan pelaku usaha (barang dan/atau jasa) dengan negara dalam memelihara keselamatan dan keamanan masyarakat (konsumen), maka tanggung jawab pelaku usaha didasarkan pada criminal liability atau pertanggungjawaban pidana, yaitu tanggung jawab pidana dari pelaku usaha (barang dan/atau jasa) atas tergantungnya keselamatan dan keamanan masyarakat (konsumen). (Johannes Gunawan, makalah seminar, Jakarta 1999: 4)

Sanksi Pidana yang dikenakan pada pelaku usaha dalam Criminal Liability, selain sanksi pidana sebagaimana yang diberlakukan pada contractual liability, profesisional liability, dan product liability dapat juga juga diberlakukan, ditambah dengan sanksi pidana lainnya, yakni berupa perampasan barang tertentu, pengumuman keputusan hakim, pembayaran ganti rugi, perintah penghentian kegiatan tertentu yang menyebabkan timbulnya kerugian konsumen, kewajiban penarikan barang dari peredaran, ataun pencabutan izin usaha.

Dalam UU Perbankan diatur mengenai sanksi jika terdapat pelanggaran terhadap rahasia simpanan nasabah. Di jelaskan dalam Pasal 47 UU Perbankan, yakni : "Barang siapa tanpa membawa perintah tertulis atau izin dari Pimpinan Bank Indonesia sebagaimana dimaksud dalam Pasal 41, Pasal 41A, dan Pasal 42, dengan sengaja memaksa bank atau Pihak Terafiliasi untuk memberikan keterangan sebagaimana dimaksud dalam Pasal 40, diancam dengan pidana penjara sekurang-kurangnya 2 (dua) tahun dan paling lama 4 (empat) tahun serta denda sekurang-kurangnya Rp 10.000.000.000,00 (sepuluh miliar rupiah) dan paling banyak Rp 200.000.000.000,00 (dua ratus miliar rupiah). Kemudian, ayat (2) mengatakan " (2) Anggota Dewan Komisaris, Direksi, pegawai bank atau Pihak Terafiliasi lainnya yang sengaja memberikan keterangan yang wajib dirahasiakan menurut Pasal 40, diancam dengan pidana penjara sekurang-kurangnya 2 (dua) tahun serta denda sekurangkurangnya Rp 4.000.000.000,00 (empat miliar rupiah) dan paling banyak Rp 8.000.000.000,00 (delapan miliar rupiah)."

Yang dimaksud dengan pihak terafiliasi, menurut Pasal 1 angka 22 UU Perbankan adalah:

a. anggota Dewan Komisaris, pengawas, Direksi atau kuasanya, pejabat, atau karyawan bank;

b. anggota pengurus, pengawas, pengelola atau kuasanya, pejabat, atau karyawan bank, khusus bagi bank yang berbentuk hukum koperasi sesuai dengan peraturan perundang-undangan yang berlaku;

c. pihak yang memberikan jasanya kepada bank, antara lain akuntan publik, penilai, konsultan hukum dan konsultan lainnya;

d. pihak yang menurut penilaian Bank Indonesia turut serta mempengaruhi pengelolaan bank, antara lain pemegang saham dan keluarganya, keluarga Komisaris, keluarga pengawas, keluarga Direksi, keluarga pengurus;

\section{Kesimpulan}

a. Perbankan menjadi salah satu aspek yang diperhitungkan dan diperhatikan oleh suatu Negara. Hal ini disebabkan karena tujuan dari didirikannya bank itu sendiri, tujuannya adalah untuk menunjang pelaksanaan pembangunan nasional dalam rangka meningkatkan pemerataan, pertumbuhan, ekonomi dan stabilitas ke arah peningkatan kesejahteraan rakyat banyak. Perbankan disamping sebagai lembaga penyedia jasa keuangan, juga sebagai lembaga yang mampu menghimpun dana serta menyalurkannya kembali masyarakat. Perkembangan teknologi turut serta 
mempengaruhi dunia perbankan. Yang awalnya orang harus menunggu berjam-jam hanya untuk bertransasksi ataupun melakukan pinjaman ke bank. Hal ini berpengaruh terhadap jasa perbankan, mulai merebaknya mobile banking yang kemudian diikuti oleh maraknya pinjaman online atau fintech lending menjadi solusi serta permasalahan yang baru. UU No. 10 Tahun 1998 Tentang Perbankan menjadi regulasi dalam hal perbankan. Kewaspadaan akan kerahasiaan nasabah penyimpan dan/ ataupun nasabah peminjam turut masuk pula dalam UU Perbankan tersebut.

b. Kerahasiaan bank merupakan sesuatu yang perlu untuk dilindungi, dan nasabah sebagai konsumen dari bank dalam hal ini sebagai pelaku usaha. Kerahasiaan bank diatur dalam UU No. 10 Tahun 1998 Tentang Perbankan serta diatur pula dalam aturan pelaksananya yakni Peraturan Bank Indonesia No. 2/19/PBI/2000 tentang Persyaratan dan Tata Cara Pemberian Perintah atau Izin Tertulis Membuka Rahasia Bank. kewajiban pihak bank dan pihak terafiliasi untuk mera-hasiakan keterangan tersebut, kecuali hal itu tidak dilarang oleh undang-undang.

\section{Saran}

a. Apabila ditelusuri batasan pengertian rahasia bank di Indonesia, maka akan teriihat ketidakjelasan pengaturannya, baik dalam Undang-undang No. 23 Tahun 1964, Undangundang No. 14 Tahun 1967. Undang-undang No. 7 Tahun 1992, maupun dalam Undangundang No. 10 Tahun 1998Ketidakjelasan pada peraturan pemndang-undangan sebelum 1998 bersumber dari ruang lingkup rahasia bank yang terlalu luas, meliputi "keadaan keuangan nasabah" dan "hal-hal lain dari nasabah bank yang harus dirahasiakan menurut kelaziman dalam dunia Perbankan". Berlakunya Undang-undang No. 10 Tahun 1998 tentang Perubahan atas Undang-undang No. 7 Tahun 1992 tentang Perbankan mengurangi ketidakjelasan. rahasia bank, dengan menyebutkan rahasia bank adalah segala sesuatu yang berhubungan dengan keterangan mengenai penyimpanan dan simpanannya. Namun, dalam Undang-undang No. 10 Tahun 1998 apa yang dimaksud dengan "segala sesuatu yang berhubungan" dan "keterangan mengenai nasabah penyimpanan dan simpanannya" tidak diatur secara jelas. Definisi tersebut meliputi unsur subjektif yang menyangkut diri nasabah penyimpan, dan unsur objektif yaitu simpanan nasabah.

b. Perlu dipersempit lagi konsep Rahasia Bank dalam penga-turan UU No. 10 tahun 1998 tentang Perubahan UU No. 7 tahun 1992 tentang Perbankan, secara lebih eksplisit. Halhal apa saja yang dapat "dibuka" untuk kepentingan hukum. Perlu kiranya ditiniau kembali tata cara untuk memperoleh izin dari Pimpinan BI dalam rangka pemeriksaan suatu perkara di pengadilan. Pengaturan yang terdapat dalam Pasal 42 ayat (2) dan ayat (3) cenderung memposisikan Pimpinan BI lebih tinggi dari Kejaksanaan Agung dan Mahkamah Agung. Karena yang berhak meminta izin, dan harus dimintakan secara tertulis, adalah Kepala/ Ketua kedua lembaga tersebut. Sedangkan hakim yang seyogianya bebas dan mandiri tidak dapat meminta izin tersebut.

\section{Daftar Pustaka}

\section{Buku}

Anwar, Moch., (1986). Tindak Pidana di Bidang Perbankan. Bandung: Alumni. Asikin \& Zainal., (1995). Pokok-Pokok Hukum Perbankan di Indonesia. Jakarta: PT Raja Grafindo Persada. Arrasjid, Chairul., (2000). Dasar-Dasar Ilmu Hukum Jakarta: Sinar Grafika.

Djumhana, Muhamad., (1996). Rahasia Bank (Ketentuan dan Penerapannya di Indonesi). Bandung: Citra Aditya Bakti. (1996). Hukum Perbankan diIndonesia. Bandung: Citra Aditya Bakti. 
Fuady, Munir., Hukum Perbankan Modern. Bandung: PT Citra Adiyta Bakti.

Susilo, Y.S., Triandaru, S., \& Santoso, A.T.B. (2000). Bank dan Lembaga Keuangan Lainnya. Jakarta: Salemba Empat.

\section{Jurnal}

Apriani, Rani, Grasia Kurniawati, dan Devi Siti Hamzah Marpaung. Perlindungan Hukum Nasabah Bank Dalam Hal Terjadinya Kesalahan Sistem Yang mengakibatkan perubahan saldo nasabah. Syiar Hukum Jurnal IImu Hukum, 18(2).135-150. doi:10.29313/shjih.v18i2.6245

Anggianti, NI Kadek Dwi, I Wayan Suardana. Pengaturan Prinsip Kepercayaan dalam melakukan Transaksi Keuangan Pada Bank.

Faisal, Fitriah. 2018. Pengaruh Prinsip Kerahasiaan Bank Terhadap Tindak Pidana Pencucucian Uang. Al-Anwal: Jurnal of Islamic Ecenomic Law, 3(1).

Izza, Aqidatul. (2018). Peran histroris perbankan dalam perekonomian indonesia. Dinar: Jurnal prodi ekonomi syari'ah. 1(1).

Nazarudin. 2006. Kewajiban dan Keterbukaan dan Prinsip Rahasia Bank di Pasar Modal. Jurnal Hukum, 24(10), 128-138.

Njatrijani, Rinitami. 2019. Perkembangan Regulasi dan pengawasan Financial Technology di Indonesia. DIPONEGORO PRIVATE LAWREVIEW. 4(1).

Simatupang, Taufik H. 2011. Asas Kerahasiaan Bank dan Pengecualiannya demi kepentingan Hukum. Forum Ilmiah, 8(2).

Pakpahan, Elvira Fitriyani, Jessica, Corris Winar, dan Andriana. 2020. Peran Otoritas Jasa Keuangan (OJK) dalam mengawasi maraknya pelayanan Financial Technology (fintech) di Indonesia. Jurnal Magister Hukum Udayana (Udayana Magister Law Journal), 9(3).

\section{Peraturan Perundang-undangan}

Undang-Undang Nomor 10 Tahun 1998 Tentang Perbankan

Undang-Undang Nomor 8 Tahun 1999 Tentang Perlindungan Konsumen

Peraturan Bank Indonesia Nomor 2/ 19/ PBI/ 2000 Tentang Persyaratan dan Tata Cara Pemberian Perintah atau Izin Tertulis Membuka Rahasia Bank

Peraturan Bank Indonesia Nomor 18/ 17/ 2016 Tentang Uang Elektronik

Peraturan Bank Indonesia Nomor 18/ 40/ PBI/ 2016 Tentang Penyelenggaraan Pemrosesan Transaksi Pembayaran

Peraturan Otoritas Jasa Keuangan Nomor 77/ POJK. 01/ 2016 Tentang Layanan Pinjam Meminjam Uang Berbasis Teknologi Informasi 